The Journal of Vitaminology 4, 88-99 (1958)

\title{
VITAMIN CONTENTS IN THE LAMPREY, ENTOSPHENUS JAPONICUS MARTENS
}

\author{
HIDEO HIGASHI, SHUICHI HIRAO, JUAMI YAMADA \\ AND RYO KIKUCHI \\ Section of Marine Product Utilization, Tokai Regional Fisheries Research \\ Laboratory, Tsukishima, Kyobashi, Tokyo
}

(Received January 9, 1958)

In Japan the lamprey, Entosphenus japonicus Martens, has often been recommended since old times as a diet efficacious for curing night blindness and tuberculosis because of its rich source of nourishment. Fujimaki (1), Miura (2) and Nakamiya (3), reported the nutritive factors in the lamprey on different occasions and maintained that the vitamin A content of its flesh is several times as much as that of fresh butter or oil of the eel.

Based on the works carried out by the authors in regard to the biochemical significance and variabiltiy of vitamin A in fish of different species, it can be said that the lamprey is a very unusual fish in various vitaminological aspects. The present paper deals with the results of the experiments conducted with the samples caught in the Mogami River, Yamagata Prefecture, in various seasons during 1951 to 1956 .

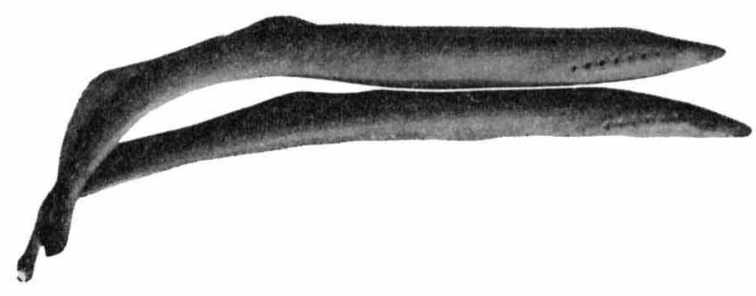

Fis. 1 External Appearance of the Lamprey

The lamprey (Fig. 1) are caught in rivers flowing into the Japan Sea. In autumn mature lampreys come up in large groups from the sea to the rivers for spawning. As their gonads mature during a few months, usually from April to May, of freshwater life, they spawn in the upper streams.

The hatched larvae descend the river into the sea and grow up to maturity. As yet, it remains quite unsettled how many years they stay in the sea, though they are believed to remain at the bottom of the sea for about seven years. In fishing districts the lamprey caught are kept for several days in a small cage without food until being shipped to market.

\section{EXPERIMENTAL}

\section{Methods and Materials}

Vitamin A was determined by estimating the optical density at absorption 
maximum, $325 \mathrm{~m} \mu$, of the unsaponifiable matter of the oil. The results were subjected to the Morton-Stubbs' correction. For the samples in which no correction was made because of some difficulties, a colorimetric method with

TABLE I

Vitamin A Content in Various Parts of Lamprey

\begin{tabular}{|c|c|c|c|c|c|c|c|c|c|c|c|c|c|c|c|}
\hline \multirow{2}{*}{ 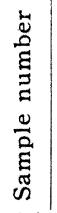 } & \multirow[b]{2}{*}{$\left|\begin{array}{l}x \\
0 \\
\tilde{N}\end{array}\right|$} & \multirow[b]{2}{*}{$\left|\begin{array}{l}5 \\
5 \\
00 \\
\Xi \\
\Xi \\
0 \\
0 \\
0 \\
0\end{array}\right|$} & \multirow[b]{2}{*}{ 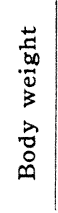 } & \multicolumn{3}{|c|}{ Flesh } & \multicolumn{4}{|c|}{ Liver } & \multicolumn{4}{|c|}{ Sexual organ } & \multirow{2}{*}{ 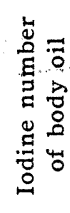 } \\
\hline & & & & 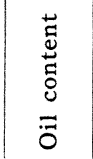 & 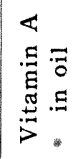 & 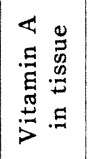 & $\begin{array}{l}\frac{\vec{E}}{\infty} \\
.00 \\
\overrightarrow{0}\end{array}$ & 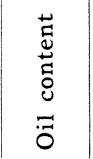 & 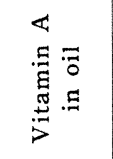 & 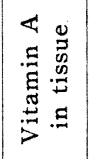 & $\begin{array}{l}\overrightarrow{0} \\
.00 \\
\overrightarrow{0} \\
\vec{B}\end{array}$ & 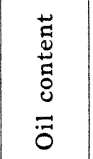 & 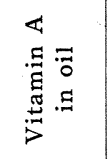 & 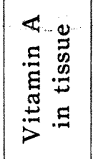 & \\
\hline & & $\mathrm{cm}$ & $g$ & percent & I.U./g & $I . U . / g$ & $g$ & percent & $I . U . / g$ & $\mid . U . / g$ & $g$ & |percent & I.U. $/ \mathrm{g}$ & $I . U . / g$ & \\
\hline 1 & of & 47.6 & 205 & 16.0 & 3.900 & 625 & 4.5 & 2.7 & 169,000 & 4.570 & 32 & 12.2 & 1.590 & 194 & 129 \\
\hline 2 & $\mid \begin{array}{l}1 \\
9 \\
9\end{array}$ & 46.6 & 204 & 1 & & & & 2 & & 0 & 41 & & & 181 & 111 \\
\hline 3 & 9 & 45.7 & 186 & 16.1 & 1,840 & 297 & 5.8 & 2. & 59 , & 1,345 & 44 & & & 99 & 128 \\
\hline 4 & i & 49.2 & 202 & 20. & 1,4 & 28 & 4.8 & 4 & 71 & & 20 & & & 162 & 125 \\
\hline 5 & $\begin{array}{ll}1 \\
0\end{array}$ & 43.8 & 141 & 15.5 & & 8 & 4.8 & 3. & 200 & & 12 & & & 425 & 132 \\
\hline 6 & is & 45.1 & 132 & 5.5 & 1,8 & 99 & 4.8 & 5. & 92 , & 5,010 & 14 & 13 & 10,120 & 1,355 & 134 \\
\hline 7 & of & 40.4 & 124 & 15.3 & 4,1 & 632 & 1.8 & 19 & 45 & 8,810 & 9 & & - & -1 & 119 \\
\hline 8 & 우 & 46.2 & 123 & 10.8 & 2,7 & & 2.5 & & & & $\ldots$ & - & - & - & 131 \\
\hline 9 & 9 & 43.4 & 106 & 11.2 & 3,0 & 340 & 2.3 & 0 & & 0 & - & - & - & 一 & 125 \\
\hline 10 & o & 41.3 & 100 & 10 & 3,3 & & 1.5 & & & 0 & - & - & - & - & 129 \\
\hline 11 & क & 46.2 & 136 & 18 & & & & & & & - & . & 一 & - & 138 \\
\hline 12 & |̂े & 45.6 & 182 & 13 & 4, & & 3.2 & & & 30 & 17 & 2.26 & 42,800 & 966 & 130 \\
\hline 13 & 昘 & 48.6 & 182 & 14 & 1,9 & 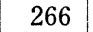 & 3.0 & & & 3,720 & 8 & 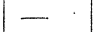 & - & & 124 \\
\hline 14 & $\hat{0}$ & 46.7 & 176 & & & & & & & & 18 & 1 & 119, & 2.100 & 113 \\
\hline 15 & 今ิ & 45.2 & 167 & 14 & 1 & & 2.8 & & & & 15 & 2 & 173,000 & 4,180 & 135 \\
\hline 16 & |̂े & 44.6 & 164 & 9 & 3,7 & & 3.8 & & & 4,250 & 11 & - & - & & 136 \\
\hline 17 & 全 & 43.6 & 128 & 15 & 2 & & 1.0 & & & & 11 & 3.5 & 146,000 & 5,220 & 124 \\
\hline 18 & |̂े & 46.8 & 169 & 16 & 1,6 & 26 & 2.5 & & & & 8 & - & - & - & 143 \\
\hline 19 & $\hat{\delta}$ & 50.7 & 167 & & & & 3.0 & & & & - & - & - & - & 133 \\
\hline 20 & 昘 & 44.3 & 136 & & & & & & & & - & - & - & - & 132 \\
\hline 21 & $\hat{0}$ & 45.3 & 127 & 15 & 2 & & 2.5 & & 20 , & 4,480 & - & - & - & - & 127 \\
\hline 22 & $\hat{\delta}$ & 47.4 & 141 & 12.7 & 4,0 & 5. & 2.7 & 18.8 & 26,500 & 4,980 & - & - & - & - & 131 \\
\hline 23 & $\hat{0}$ & 51.3 & 263 & 16 & & 42 & 4.5 & & & 3,760 & 12.8 & & - & 1,740 & \\
\hline 24 & 0 & 48.2 & 236 & 19 & 3, & & 4.8 & $\ldots$ & - & & 39.2 & 22.4 & 1,650 & 371 & \\
\hline 25 & $\hat{\delta}$ & 47.1 & 205 & 27.0 & 1,640 & 444 & 4.2 & - & - & 4,970 & 8.2 & & - & 2,350 & \\
\hline 26 & ;. & 46.5 & 185 & & & & 3. & - & - & 00 & 10.5 & - & - & . & \\
\hline 27 & q & 43.5 & 181 & 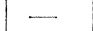 & - & - & 5.3 & - & - & 00 & 28.0 & 17. & 4,470 & 798 & \\
\hline 28 & 9 & 51.5 & 220 & 17.0 & 1,460 & 248 & 6.5 & 14.6 & 15,200 & 20 & 14.2 & 19 & & 69 & \\
\hline 29 & i & 53.0 & 200 & & & & & & & 3,025 & 13.4 & 17. & 130 & 22 & \\
\hline 30 & $\hat{\delta}$ & 45.5 & 140 & & & & 2 & 20 & & 2,520 & - & & & & \\
\hline 31 & 9 & 54.3 & 250 & 12 & & & 5.2 & 6 & 26 , & 1,815 & 23.7 & 16 & 2,1 & 348 & \\
\hline 32 & i & 53.0 & 250 & & & & & & & & 21 & & & 37 & \\
\hline 33 & o & 56.5 & 290 & 18 & 1 , & & & & & & 18 & 22 & & 22 & \\
\hline 34 & $\hat{\delta}$ & 50.5 & 200 & 13 & 3,6 & & 2.7 & 18 & 29 & 00 & 11. & 1 & & 57 & \\
\hline 35 & $\uparrow$ & 50.5 & 182 & 18. & 5,320 & & 3.6 & 29 & 23,600 & & 11. & 2. & 3,640 & 75 & \\
\hline 36 & ơ & 54.0 & 286 & - & - & & 7 & - & - & 70 & 21.2 & - & - & 178 & \\
\hline 37 & 9 & 52.0 & 244 & - & - & 26 & 6.2 & - & - & 1,750 & 19.7 & 一 & 一 & 147 & \\
\hline 38 & $\hat{0}$ & 44.8 & 118 & - & - & 58 & 2.0 & - & - & & - & - & - & & \\
\hline 39 & $\hat{\delta}$ & 42.7 & 105 & - & - & . & & - & - & & 5.5 & - & - & 452 & \\
\hline 40 & 昘 & 57.6 & 271 & 17.9 & 1,260 & 22 & 4.9 & 27.0 & 7,0 & 1,900 & 15.3 & 5. & & U & \\
\hline 41 & q & 55.5 & 243 & 21 & $7 \varepsilon$ & 1 & & & & & 17.4 & & & 231 & \\
\hline 42 & o. & 53.2 & 230 & 17 & & & & & & & 16. & 18 & & 167 & \\
\hline 43 & $\hat{0}$ & 53.0 & 213 & 20. & 2,060 & 42 & 4 & & & 17,300 & 11 & 5 & 7,560 & 428 & \\
\hline 44 & 9 & 51.8 & 225 & 19 & & 13 & 4 & 10 & & & 15 & 18 & & 117 & \\
\hline 4 & 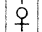 & 51 & 205 & 2 & & & & & & & 12 & & & 0 & \\
\hline 46 & $\dot{q}$ & & 205 & 21 & 1,2 & 25 & 5 & 10. & & & 15.2 & 20 & & 221 & \\
\hline 4 & 9 & 51 & 200 & 18 & & 32 & 5 & 5. & & & 15.9 & 16 & 1,430 & 234 & \\
\hline 48 & + & & 232 & 19.8 & 1,205 & 236 & 4.8 & 63 & 63,000 & 3,950 & 17.3 & 22.0 & 990 & 218 & \\
\hline
\end{tabular}




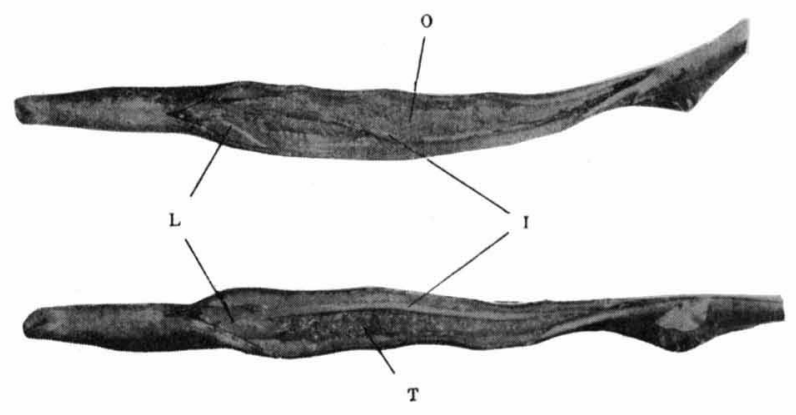

FIG. 2 Anatomy of the Lanprey

$\mathrm{L}$, liver ; $\mathrm{T}$, testis ; $\mathrm{O}$, ovary ; I, intestine antimony trichloride was adopted. Thiamine and riboflavin were determined by thiochrome method and lumiflavin method, respectively; vitamin $B_{6}$ and $B_{12}$ by microbioassay using Lactobacillus leichmanii; folic acid by Streptcoccus faecalis and pantothenic acid by Lactobacillus arabinosus. In each fresh sample, the weights of bodies, livers and gonads

(Fig. 2), and their oil and vitamin A contents were determined with the results shown in Table I.

\section{RESULTS}

\section{Flesh}

\section{Vitamin A Content of Fresh Fish}

Vitamin A content in the flesh per gram of tissue was found to be $99-980$ I.U. (average $300 \mathrm{I} . \mathrm{U}$.$) , the highest value that has ever been observed in the$ animal flesh. For in chicken, pork, beef and other fishes, the vitamin A content has been found to be as low as $0.5-3.0 \mathrm{I}$. U. per gram of tissue. Since the authors previously found in other fishes that the vitamin A content in the flesh differs considerably depending upon the locality of the body, an experiment has been undertaken to see if the similar tendency is observed in the lamprey using

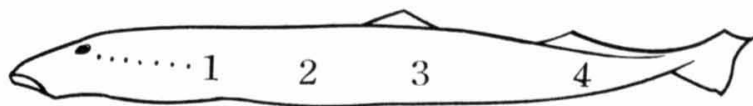

FIG. 3 Locality of the Body of a Lamprey, from where the Sample Flesh was iaken

TABLE II

Vitamin A Content at Various Localities of Flesh

See Fig. 3

\begin{tabular}{c|c|c|c|c}
\hline \hline $\begin{array}{c}\text { Sample } \\
\text { Number }\end{array}$ & $\begin{array}{l}\text { Locality of the } \\
\text { body }\end{array}$ & Oil content & Vitamin A in oil & Vitamin A in tissue \\
\hline \multirow{3}{*}{33} & & per cent & I.U./g & I.U./g \\
& 1 & 14.7 & 1910 & 281 \\
& 2 & 23.5 & 1310 & 308 \\
34 & 3 & 19.9 & 1120 & 224 \\
& 4 & 15.3 & 1010 & 155 \\
35 & 1 & 13.8 & 4700 & 650 \\
& 3 & 16.4 & 3160 & 520 \\
& 4 & 11.0 & 3000 & 330 \\
& 1 & 22.4 & 9950 & 8690 \\
& 3 & 13.9 & 3830 & 501 \\
\hline
\end{tabular}



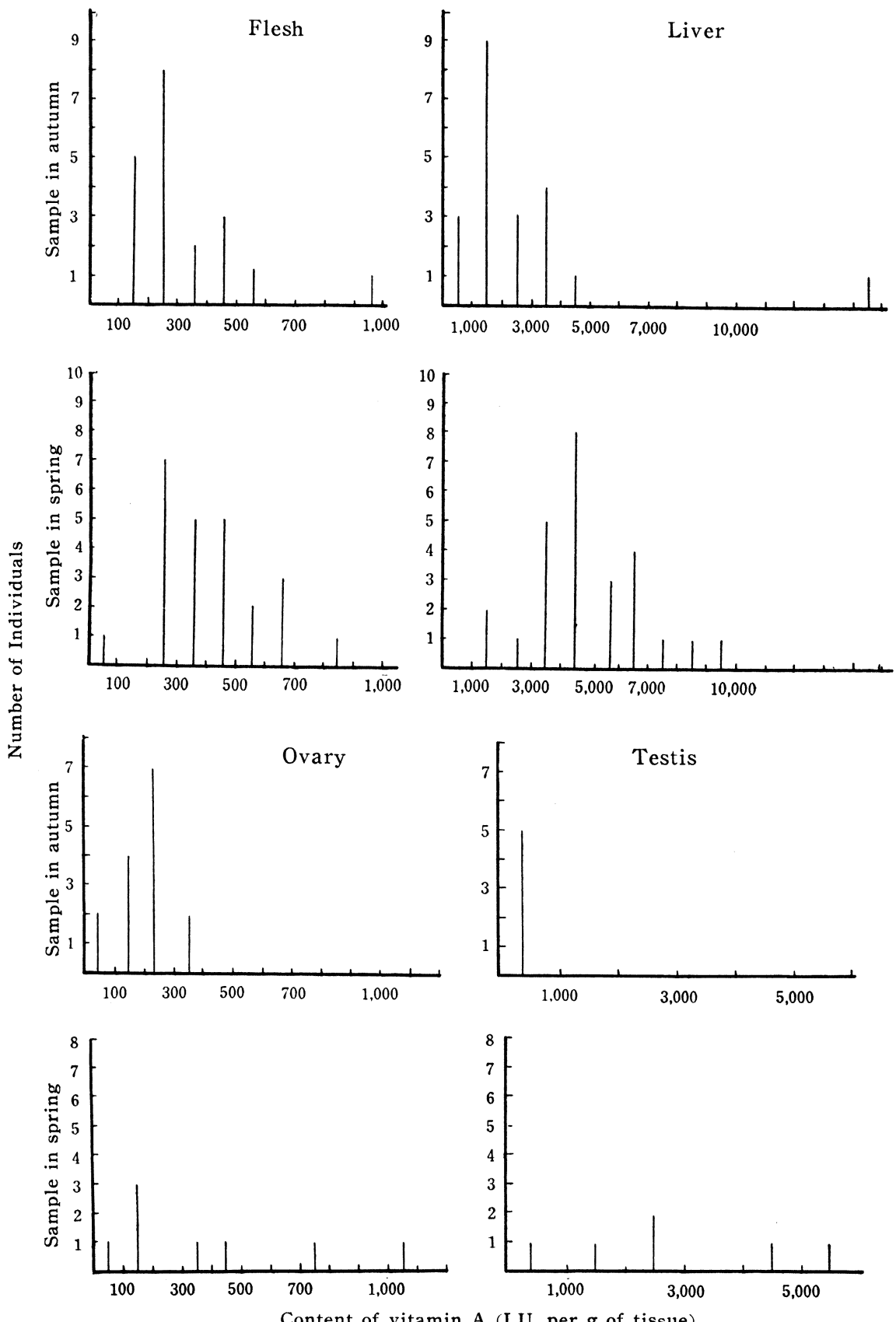

Fif. 4 Frequency of the Samples Varying in Amounts of Vitamin A According to Organs and Seasons 
the samples taken from the localities shown in Fig. 3 . As the results shown in Table II reveal, the oil and vitamin A contents of flesh differ considerably depending upon the locality. The content of vitamin A in the body oil was found richer in the anterior part than in the posterior.

According to a previous work by the authors (4), the relation between the oil content $(F \%)$ in the flesh of any fish and the vitamin A content (I.U.) of the oil can be expressed by the equation $A F^{a}=$ const, where $a$ is a constant. When the results shown in Tables I and II were tested, however, the oil content of the flesh and the vitamin A content in the oil were found quite indifferent. Comparing the samples (Nos. 28-48, Table I) caught prior to the spawning stage with those (Nos. 1-25) caught during the spawning season, one may notice that the vitamin A contained in the former group is by far richer than in the latter (Fig. 4). The iodine number of the body oil, 111-138, showed no relation at all with the body weight, oil content or vitamin A content of the flesh.

\section{Liver}

In the liver, generally weighing 2.3 per cent of the body, vitamin A was found 1,010-17,300 I. U./g, nearly 10 times as much as that of the flesh. Though

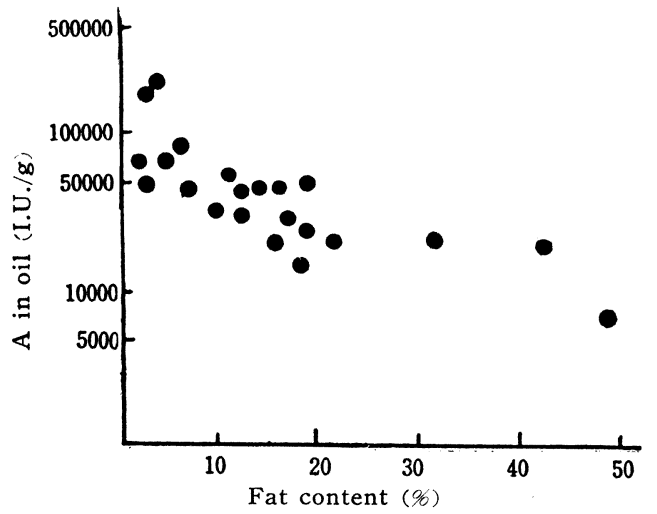

Frg. 5 Relation between Vitamin A Content and Fat Content in Liver the livers of tunas and dogfish sometimes show still higher level than above, there is no doubt that vitamin A level in the lamprey liver is definitely higher than that of ordinary fishes. In regard to the vitamin A content, the similar seasonal tendency has been observed in the livers as was the case in the flesh. A relation between the oil content of the liver and the vitamin $A$ in that oil is shown in Fig. 5; the lower the oil content of the liver, the richer was vitamin A in the oil.

\section{Gonads}

In the spawning season, the testis of lamprey contains $966-5,220$ I. U. of vitamin A per gram of tissue. Since in the testis of ordinary fishes or animals the vitamin A is hardly detectable, it is most remarkable to find that only the lamprey contains such a large quantity of the vitamin in the testis. Vitamin A in the gonads of lamprey is far richer in the samples of spawning season than those of autumn, though it varies considerably depending upon individuals, especially in samples obtained in spawning season.

\section{Kidney}

On some samples, the vitamin A content of kidney was tested (Table III). According to the authors' experiments (5), sharks have the kidney rich in vitamin A. Nevertheless, the lamprey kidney contains the vitamin ten times as 
TABLE III

Vitamin A Content in Kidney

\begin{tabular}{c|c|c|c|c}
\hline $\begin{array}{l}\text { Sample } \\
\text { number }\end{array}$ & Weight & Oil content & Vitamin A in oil & Vitamin A in tissue \\
\hline & $g$ & per cent & I.U./g & I.U./g \\
40 & 2.1 & 8.1 & 17,000 & 1,450 \\
41 & 2.0 & 5.1 & 50,800 & 2,630 \\
42 & 1.8 & 4.0 & 50,750 & 2,010 \\
43 & 1.8 & 11.8 & 65,600 & 7,760 \\
44 & 1.6 & 4.7 & 33,100 & 1,550 \\
45 & 1.4 & 5.5 & 28,100 & 1,540 \\
46 & 1.6 & 6.5 & 40,000 & 2,600 \\
47 & 1.3 & 6.4 & 79,100 & 2,060 \\
48 & 1.7 & 6.2 & 39,000 & 2,400 \\
\hline
\end{tabular}

much as that of sharks.

\section{Digestive Organs}

Vitamin A in the digestive organs of lamprey was determined. To distinguish the stomach from the intestine by their appearences was difficult because the organs look just like a single tube. A pale yellow, milky substance observed in the tube did not seem to be the residue of the diet, because all the sample fishes were kept alive more than a week without any food. Instead, the milky substance may possibly have been excreted in the intestine from the tissue. As shown in Table $1 \mathrm{~V}$, the vitamin $\mathrm{A}$ content in the tract was found extraordinary higher than that of the flesh, liver or gonads.

TABLE IV

Contents of Vitamin $A$ and Oil in Digestive Organs

Sample Nos. 40-48 were caught in December 1956.

Sample Nos. 49-53 were caught in February 1955.

\begin{tabular}{|c|c|c|c|c|c|c|c|c|}
\hline \multirow{2}{*}{ 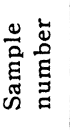 } & \multicolumn{4}{|c|}{ Digestive organs } & \multicolumn{4}{|c|}{ Contents in digestive organs } \\
\hline & Weight & $\begin{array}{l}\text { Oil } \\
\text { content }\end{array}$ & $\begin{array}{l}\text { Vitamin A } \\
\text { in oil }\end{array}$ & $\begin{array}{l}\text { Vitamin A } \\
\text { in tissue }\end{array}$ & Weight & $\begin{array}{l}\text { Oil } \\
\text { content }\end{array}$ & $\begin{array}{l}\text { Vitamin A } \\
\text { in oil }\end{array}$ & $\begin{array}{l}\text { Vitamin A } \\
\text { in contents }\end{array}$ \\
\hline & $g$ & per cent & I.U./g & I.U./g & $g$ & per cent & $I . U . / g$ & I.U. $/ g$ \\
\hline 40 & 1.35 & 9.06 & 422,000 & 38,100 & 1.20 & 5.34 & 122,000 & 6,520 \\
\hline 41 & 2.07 & 6.98 & 438,000 & 30,600 & 1.85 & 4.20 & 94,800 & 3,980 \\
\hline 42 & 1.63 & 6.81 & 394,000 & 26,800 & 1.12 & 6.40 & 183,200 & 11,720 \\
\hline 43 & 1.22 & 15.67 & 725,000 & 113,600 & 0.20 & 9.80 & 93,200 & 9,120 \\
\hline 44 & 0.78 & 6.24 & 292,000 & 18,200 & 0.77 & 8.15 & 197,600 & 16,100 \\
\hline 45 & 1.09 & 6.39 & 293,000 & 18,700 & 0.82 & 7.67 & 120,300 & 9,240 \\
\hline 46 & 0.87 & 9.87 & 508,000 & 50,200 & 0.73 & 6.30 & 225,500 & 14,200 \\
\hline 47 & 1.13 & 11.62 & 572,000 & 66,500 & 0.62 & 8.18 & 222,500 & 18,200 \\
\hline 48 & 1.32 & 8.74 & 517,000 & 45,200 & 1.13 & 5.56 & 112,600 & 6,260 \\
\hline 49 & 0.51 & - & - & 73,700 & 0.90 & - & - & 4,450 \\
\hline 51 & 0.42 & - & - & 113,200 & 0.60 & - & - & 36,700 \\
\hline 52 & 0.38 & - & - & 108,000 & 0.40 & — & - & 69,900 \\
\hline 53 & 0.37 & 一 & - & 95,500 & 0.55 & - & - & 32,200 \\
\hline
\end{tabular}

\section{Distribution in the Body}

The distribution of vitamin A in the body of lamprey has been calculated 
(Table V). Vitamin A in the flesh and digestive organ accounts for 29-48, and 25-53 per cent of the total vitamin A, respectively; both put together amounting to 80 per cent of the total, whereas the remaining 20 per cent of the total being shared among the liver, kidney and gonads.

These data emphatically suggest that the lamprey is quite an exceptional speices of fish. For, in most fishes, the liver, sometimes together with pyrolic caeca, accounts for nearly 90 per cent of the total vitamin $A$ in the body.

TABLE V

Distribution of Vitamin A in Body

\begin{tabular}{|c|c|c|c|c|c|c|}
\hline $\begin{array}{l}\text { Sample } \\
\text { number }\end{array}$ & Sex & Flesh & Liver & Sexual organ & Kidney & $\begin{array}{l}\text { Digestive organ } \\
\text { excluding contents }\end{array}$ \\
\hline & & per cent & per cent & per cent & per cent & per cent \\
\hline 40 & $\hat{\delta}$ & 43.8 & 7.4 & 3.3 & 2.5 & 43.0 \\
\hline 43 & 全 & 25.5 & 23.7 & 1.6 & 4.6 & 45.3 \\
\hline 41 & 웅 & 37.2 & 7.5 & 4.3 & 5.3 & 45.6 \\
\hline 42 & 우 & 34.8 & 9.8 & 3.3 & 4.3 & 47.8 \\
\hline 44 & 우 & 53.0 & 10.2 & 4.1 & 4.1 & 28.6 \\
\hline 45 & 우 & 53.2 & 7.8 & 4.7 & 3.1 & 31.2 \\
\hline 46 & 웅 & 43.1 & 6.9 & 2.9 & 3.9 & 43.1 \\
\hline 47 & 오 & 35.8 & 8.5 & 2.6 & 4.6 & 43.8 \\
\hline 48 & o & 34.8 & 14.8 & 3.0 & 3.0 & 44.4 \\
\hline
\end{tabular}

\section{Lamprey Larvae}

The larvae of lamprey are brownish in color and semitransparent at the earliest stage, then gradually change into the young form. Some samples in a very young stage collected from upper streams of the Mogami showed a comparatively high level of vitamin A even at that stage (Table VI), though the older ones contained vitamin $\mathrm{A}$ in the flesh and liver more than the younger.

TABLE VI

Vitamin A Content in Young Fish

\begin{tabular}{|c|c|c|c|c|c|c|c|c|c|c|}
\hline \multirow{2}{*}{ 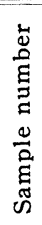 } & \multirow[b]{2}{*}{$\begin{array}{l}5 \\
5 \\
0 \\
\Xi \\
0 \\
0 \\
0 \\
0\end{array}$} & \multirow[b]{2}{*}{ 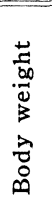 } & \multicolumn{3}{|c|}{ Flesh } & \multicolumn{2}{|c|}{ Liver } & \multicolumn{2}{|c|}{$\begin{array}{l}\text { Internal } \\
\text { organs }\end{array}$} & \multirow[b]{2}{*}{ Notes } \\
\hline & & & 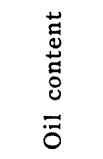 & 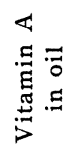 & 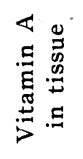 & $\begin{array}{l}\frac{\vec{t}}{60} \\
\frac{00}{0} \\
3\end{array}$ & 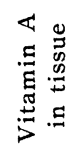 & $\begin{array}{l}\frac{\vec{n}}{00} \\
\stackrel{00}{0} \\
\overrightarrow{3}\end{array}$ & 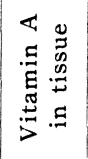 & \\
\hline & $\mathrm{cm}$ & $g$ & per cent & $I . U . / g$ & I.U./g & $g$ & $1 . U . / \mathrm{g}$ & $g$ & $I . U \cdot / g$ & \\
\hline $\begin{array}{l}1 \\
2 \\
3 \\
4 \\
5\end{array}$ & $\begin{array}{l}16.5 \\
16.0 \\
14.3 \\
13.7 \\
13.0\end{array}$ & $\begin{array}{l}6.6 \\
6.9 \\
4.7 \\
4.1 \\
3.0\end{array}$ & $\begin{array}{r}10.25 \\
8.48 \\
7.63 \\
5.20 \\
5.45\end{array}$ & $\begin{array}{l}122 \\
156 \\
142 \\
172 \\
154\end{array}$ & $\begin{array}{r}12.5 \\
13.2 \\
10.1 \\
8.6 \\
8.4\end{array}$ & $\begin{array}{l}0.061 \\
0.059 \\
0.079 \\
0.042 \\
0.042\end{array}$ & $\begin{array}{l}440 \\
406 \\
216 \\
286 \\
362\end{array}$ & $\begin{array}{l}0.423 \\
0.399 \\
0.168 \\
0.285 \\
0.139\end{array}$ & $\begin{array}{r}37.5 \\
62.6 \\
160.0 \\
31.7 \\
105.0\end{array}$ & $\begin{array}{l}\text { Some green vege- } \\
\text { table-like substance } \\
\text { was observed in the } \\
\text { intestine. }\end{array}$ \\
\hline 6 & 10.6 & 2.2 & 3.69 & 256 & 9.5 & 0.025 & 251 & 0.123 & 75.3 & $\left\{\begin{array}{l}\text { Before metamorpho- } \\
\text { sis, the bodys howed } \\
\text { a semi-transparent } \\
\text { brown colour. }\end{array}\right.$ \\
\hline
\end{tabular}




\section{Vitamin A Content in Dried Lamprey}

The lamprey is often sold in a dried form at special drug stores. The drying process is simple and needs neither salt nor anything more than keeping the fish in an airy shade. Tests of some samples from market yielded very rich contents of vitamin $A$ as given in Table VII, proving the dried form as

TABLE VII

Vitamin A Content of Dried Lamprey

\begin{tabular}{c|c|c|c|c|c}
\hline $\begin{array}{l}\text { Sample } \\
\text { number }\end{array}$ & $\begin{array}{l}\text { Body } \\
\text { length }\end{array}$ & $\begin{array}{l}\text { Body } \\
\text { weight }\end{array}$ & $\begin{array}{l}\text { Oil content } \\
\text { in flesh }\end{array}$ & $\begin{array}{l}\text { Vitamin A } \\
\text { in oil }\end{array}$ & $\begin{array}{l}\text { Vitamin A } \\
\text { content in flesh }\end{array}$ \\
\hline & cm & $\boldsymbol{g}$ & per cent & I.U./g & I.U./g \\
53 & 51.5 & 90.0 & 37.5 & 974 & 365 \\
54 & 42.5 & 55.0 & 39.5 & 4,060 & 1,620 \\
55 & 50.5 & 97.0 & 42.0 & 3,700 & 1,550 \\
56 & 48.5 & 87.0 & 46.8 & 3,760 & 1,760 \\
57 & 49.5 & 97.0 & 46.4 & 1,200 & 550 \\
58 & 43.7 & 54.0 & 44.0 & 2,680 & 980 \\
\hline
\end{tabular}

an excellent source of vitamin A. In an experiment to see the loss of vitamin A during the drying process, the fresh sample with the viscera removed, was washed in water, dried in an outdoor shade, after testing vitamin A on a part of the body. Upon drying, vitamin A was tested with a piece of the sampls taken from the same locality as tested previously. In two samples dried for 18 days, vitamin $\mathrm{A}$ of the oil was found to have decreased during the drying process, whereas in three samples dried for 40 days, the vitamin increased remarkably (Table VIII). In the absence of a conclusive reason, a possible

TABLE VIII

Change in Vitamin A Content during the Production of Dry Lamprey

\begin{tabular}{|c|c|c|c|c|c|}
\hline \multirow{2}{*}{$\begin{array}{l}\text { Sample } \\
\text { number }\end{array}$} & \multicolumn{2}{|c|}{ Fresh state } & \multirow{2}{*}{$\begin{array}{l}\text { Number of } \\
\text { days for } \\
\text { drying }\end{array}$} & \multicolumn{2}{|c|}{ Dried state } \\
\hline & Oil conteni & Vitamin $A$ in oil & & Oil content & Vitamin $A$ in oi i \\
\hline & per cent & $I . U . / g$ & days & per cent & $I . U . / g$ \\
\hline 60 & 19.6 & 1,150 & 18 & 41.5 & 770 \\
\hline 61 & 15.5 & 3,770 & 18 & 50.9 & 2,020 \\
\hline 62 & 16.2 & 2,620 & 40 & 42.0 & 4,150 \\
\hline 63 & 19.5 & 3,580 & 40 & 31.9 & 6,300 \\
\hline 64 & 27.0 & 1,640 & 40 & 41.5 & 2,710 \\
\hline
\end{tabular}

explanation of the phenomena is as follows. While the locality from where the sample had been taken at the beginning might have been poorer in vitamin A, it was supplied during the course of preparation with some vitamin-richer oil transferred from elsewhere and eventually tested. Though the attempt failed to assess the loss of vitamin $A$ in the drying process, it is certain that the lamprey contains much vitamin $A$ even in the dried materials.

\section{Contents of Water-Soluble Vitamins}

Tables IX and $X$ present the contents of thiamine, riboflavin, vitamin $B_{6}, B_{12}$, 
folic acid and pantothenic acid of the flesh, liver, gonads, skin and mucoid

TABLE IX

Contents of Vitamins in Lamprey

$\mathrm{B}_{1}$, thiamine; $\mathrm{B}_{2}$, riboflavin; $\mathrm{B}_{6}$, vitamin $\mathrm{B}_{6} ; \mathrm{B}_{12}$, vitamin $\mathrm{B}_{12}$;

$\mathrm{v}$, ventral side; $\mathrm{d}$, dorsal side.

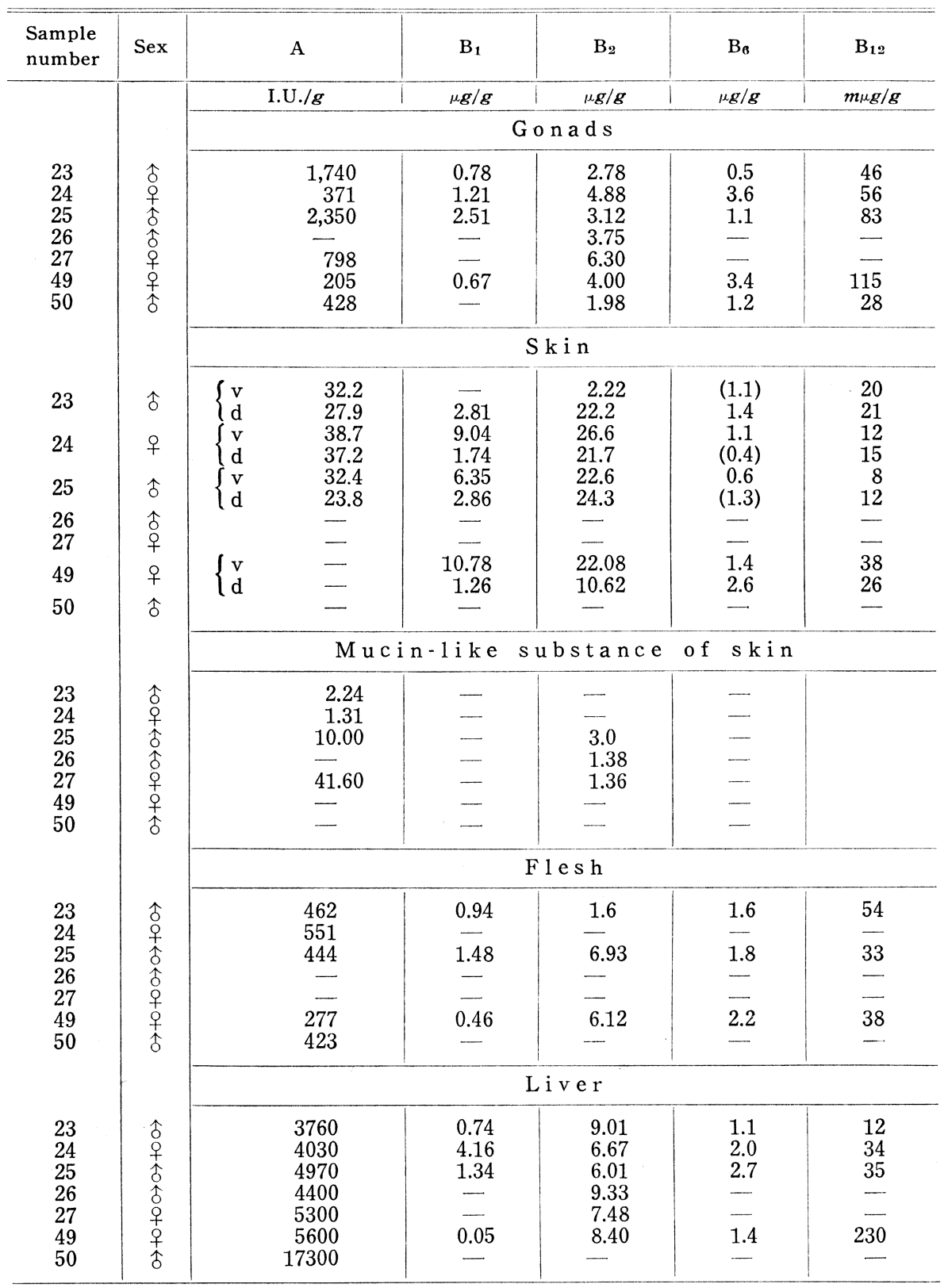


substance of the skin; Table IX including the vitamin A contents for the convenience of comparison. Vitamin $B_{12}$ in the flesh and skin as well as thiamine in the skin was assessed by far richer than in ordinary fishes. Furthermore, regarding the riboflavin content in the skin, the lamprey seems to belong to the richer group including flatfishes and eel.

As for individual variability, the riboflavin content in the liver, gonads, and skin, varied considerably but less than other water-soluble vitamins named above. In case of variability by positions of the skin, attention should be drawn to the following. Despite considerable variances in the riboflavin content between the dorsal and ventral sides of ordinary fish skin as reported by Washino (6), no such a tendency was obvious in riboflavin content of the lamprey skin. On the other hand, thiamine of the lamprey was found much more in the ventral skin than in the dorsal one, exhibiting a striking contrast with the previous assessment in which the authors found no difference in thiamine content in ordinary fish skin regardless of the positions of the skin. These findings lead to the characteristics that make the lamprey exceptional from any other fish. In Table $X$ showing the content of folic acid and pantothenic acid in the various organs of lamprey, the amount of folic acid in the liver was noticeable, though both acids in the other organs tested differed little or not at all from those in other fishes.

TABLE X

Contents of Folic Acid and Pantothenic Acid in Various Organs of Lamprey

FA, folic acid; PA, pantothenic acid.

\begin{tabular}{|c|c|c|c|c|c|c|c|c|c|c|c|c|c|}
\hline \multirow{2}{*}{$\begin{array}{l}\text { Sample } \\
\text { number }\end{array}$} & \multirow{2}{*}{$\begin{array}{l}\dot{x}^{x} \\
\stackrel{n}{n}\end{array}$} & \multicolumn{2}{|c|}{ Flesh } & \multicolumn{2}{|c|}{ Liver } & \multicolumn{2}{|c|}{ Kidney } & \multicolumn{2}{|c|}{ Heart } & \multicolumn{2}{|c|}{$\begin{array}{l}\text { Sexual } \\
\text { organ }\end{array}$} & \multicolumn{2}{|c|}{ Skin } \\
\hline & & FA & PA & FA & $\mathrm{PA}$ & $\mathrm{FA}$ & $\mathrm{PA}$ & FA & $\mathrm{PA}$ & FA & $\mathrm{PA}$ & FA & PA \\
\hline 51 & 우 & $\begin{array}{r}\mu g / g \\
0.24\end{array}$ & $\begin{array}{c}\mu g / g \\
2.8\end{array}$ & $\begin{array}{r}\mu g / g \\
5.37\end{array}$ & $\begin{array}{l}\mu g / g \\
12.0\end{array}$ & $\begin{array}{r}\mu g / g \\
0.53\end{array}$ & $\begin{array}{c}\mu g / g \\
\text { trace }\end{array}$ & $\begin{array}{r}\mu g / g \\
0.45\end{array}$ & $\begin{array}{c}\mu g / g \\
5.0\end{array}$ & $\begin{array}{r}\mu g / g \\
0.55\end{array}$ & $\begin{array}{c}\mu g / g \\
15.6\end{array}$ & $\begin{array}{r}\mu g / g \\
0.28\end{array}$ & $\begin{array}{l}\mu g / g \\
\text { trace }\end{array}$ \\
\hline 52 & $\hat{0}$ & 0.29 & 5.7 & 4.07 & 14.0 & - & - & - & - & 0.97 & 8.7 & - & - \\
\hline
\end{tabular}

The sample were caught in November 1957.

\section{DISCUSSION}

As mentioned above, the lamprey is quite extraordinary in regard to vitamins, especially vitamin A. An interesting problem - on what sort of food the fish live during their sea life - remains to be solved. At any event, however, the lamprey appears to eat and accumulate a large quantity of vitamins possibly much more than it consumes for its existence. The above supposition has been confirmed in the feeding experiments of rats with a very large quantity of vitamin A. For, the result indicated an abnormal accumulation of the vitamin in the liver as well as in the kidney and flesh, in the latter of which the vitamin A content was nearly as high as that of the lamprey. But it is difficult to analogize from the data of rats why the lamprey possesses so rich vitamin $A$ in the testis, because the results from the rat testis were hardly 
comparable with those from the lamprey's. The vitamin content in the samples in spawning season was richer than in the autumn. Nevertheless, the increase in the amount does not seem to be ascribable to natural food for the lamprey, because plants, insects or small fishes sampled in the rivers in different seasons were not so high in vitamin A or carotene as the lamprey. Judging from the information given by the local fishermen - the lamprey becomes smaller in size towards the spawning season - it is possible that the size of the same fish decreases during the course of maturity if the fish consumed its muscles for the formation of gonads or the energy source, thus resulting in the concentration of vitamin $\mathrm{A}$ in the tissue. But this seems to require further confirmation. It may be worth adding here that vitamin A of Lampetra planeri and Heptatretus okinoseanus, both taxonomically close allies to the lamprey under report, was tested. The content obtained, however, was much inferior to that of the lamprey (Table XI).

TABLE XI

Vitamin A Content in the Species Allied to Lamprey

\begin{tabular}{|c|c|c|c|c|c|c|c|}
\hline \multirow{2}{*}{ Species } & \multirow{2}{*}{$\begin{array}{l}\text { Body } \\
\text { length }\end{array}$} & \multirow{2}{*}{$\begin{array}{l}\text { Body } \\
\text { weight }\end{array}$} & \multicolumn{3}{|c|}{ Flesh } & \multicolumn{2}{|c|}{ Liver } \\
\hline & & & $\begin{array}{l}\text { Oil } \\
\text { content }\end{array}$ & $\left|\begin{array}{c}\text { Vitamin } \mathrm{A} \\
\text { in oil }\end{array}\right|$ & $\begin{array}{c}\text { Vitamin } \mathrm{A} \\
\text { in tissue }\end{array}$ & Weight & $\begin{array}{c}\text { Vitamin A } \\
\text { in tissue }\end{array}$ \\
\hline $\begin{array}{l}\text { Lampetra planeri } \\
\text { Bloch }\end{array}$ & $\begin{array}{c}c m \\
10.5-6.0\end{array}$ & $\begin{array}{c}\boldsymbol{g} \\
2.1-0.5\end{array}$ & $\begin{array}{c}\text { per cent } \\
5.88\end{array}$ & $\begin{array}{c}I . U . / g \\
118\end{array}$ & $\begin{array}{c}I . U . / g \\
6.9\end{array}$ & $\underline{-}$ & $\begin{array}{c}I . U . / g \\
-\end{array}$ \\
\hline $\begin{array}{l}\text { Heptatretus okino- } \\
\text { seanus Dean }\end{array}$ & 42.0 & 165 & 1.79 & 66.4 & 1.2 & 3.2 & 28.1 \\
\hline
\end{tabular}

Distributions of the water-soluble vitamins in the lamprey are no less peculiar than the other vitamins in giving this species an outstanding position among fish. A view that the function of these vitamins in the body of lamprey may be fairly different from that of ordinary fish has been suggested from the major findings of the present work: the high content of thiamine in the skin, its considerable variances between the ventral and dorsal sides in contrast with riboflavin which showed no difference, and remarkable richness of $\mathrm{B}_{12}$ in the flesh and skin.

In conclusion, a normal amount of a man's diet, if it consisted of the lamprey flesh, would likely afford to supply more than ten thousands I.U. of vitamin $A$, together with thiamine, riboflavin and vitamin $B_{12}$ in much larger amounts than in an ordinary meal. These may possibly be the reasons why the lamprey has been so highly evaluated in this country as an excellent source of nourishment since a number of years ago.

\section{SUMMARY}

Vitamin contents were tested with the lamprey caught in the Mogami River, Yamagata Prefecture. In the flesh, the vitamin A level was found the highest ever known in the flesh of any species of fish or animal. Anatomical parts 
rich in vitamin A next to the flesh are the liver, kidney, gonads and intestine; especially, the testis and intenstine contain extraordinary quantities of the vitamin. The distribution of vitamin $\mathrm{A}$ in the body considerably differs from that of ordinary fishes. The major part of the vitamin is accumulated in the flesh and intestine, whereas the liver possesses only a small part of it.

Samples caught in the spawning season, April and May, were found more abundant in the vitamin content than those canght in autumn. The young fish also indicated by far higher content of vitamin A than any other fish in a comparable stage.

The content of thiamine and $\mathrm{B}_{12}$ in the skin greatly exceeds that of other fishes. In the ventral skin more thiamine was found than in the dorsal skin.

\section{REFERENCES}

1. Fujimaki, Y., Reports of Nat. Inst. Nutr. 2, 171 (1928).

2. Miura, M., J., Pharmac. Soc. Jap. 46, 765 (1926).

3. Nakamiya, J., Rep. of Rikagaku Kenkyujo 4, 321 (1925).

4. Hirao, S., Yamada, J. and Kikuchi, R., Bull. Jap. Soc. Sci. Fish. 19, 1047 (1954).

5. Higashi, H., Hirao, S., Shimizu, K., Yamada, J., and Kikuchi, R., ibid. 18, 310, 349 (1953).

6. Washino, E., Vitamins, 6, 948 (1953). 